\title{
O Instituto Pasteur de São Paulo: Uma Contribuição a História das Instituições Biomédicas no Brasil
}

\author{
LUIZ ANTONIO TEIXEIRA*
}

\section{Introdução}

Este estudo trata da trajetória do Instituto Pasteur de São Paulo. Instituição criada pela iniciativa de médicos e filantropos paulistas, tinha como finalidade realizar pesquisas em variados campos da microbiologia com interesse na aplicação em saúde pública, elaborar produtos biológicos de uso humano e veterinário e proceder à produção e aplicação da vacina anti-rábica.

A recuperação da trajetória do Instituto Pasteur de São Paulo faz parte de um projeto de pesquisa realizado na Casa de Oswaldo Cruz, que visa a recuperação histórica comparativa das instituições biomédicas produtoras de imunobiológicos e de conhecimentos científicos originais, criadas a partir das duas últimas décadas do século passado. Seu objetivo é a construção de uma análise sócio-histórica que contribua para a compreensão do processo de criação e institucionalização das ciências biomédicas no Brasil.

Embora o andamento de nossas pesquisas ainda nāo possibilite um aprofundamento analítico sobre a trajetória do Instituto Pasteur de São Paulo, achamos relevante este primeiro esforço, pois inexistem informaçōes sistematizadas sobre a sua história.

Pesquisador da Casa de Oswaldo Cruz e mestrando do Instituto de Medicina Social da UERJ. 
Tomamos como marcos cronológicos o período que vai de 1903, data de sua fundação, a 1916, momento em que é incorporado ao Serviço Sanitário do Estado de São Paulo. A partir da incorporação, ele perde as funções de produção de substâncias biológicas e elaboração de pesquisas científicas, transformando-se em um laboratório destinado tão somente à produção da vacina anti-rábica e ao tratamento dos acometidos por essa doença.

Na primeira seção fazemos uma breve apreciação dos Institutos Pasteur criados no país, ressaltando suas diferenças frente à instituição francesa que os inspirou. Na seção seguinte, tratamos do desenvolvimento das primeiras instituições biomédicas em São Paulo e de sua relação com o Instituto Pasteur. A partir daí, apresentamos sua trajetória, procurando nos deter em seu desenvolvimento científico e institucional.

$\mathrm{Na}$ última seção analisamos as formas de captação de recursos do Instituto Pasteur e como elas se ligam à sua desagregação. Retomamos, nesse ponto, o processo de desenvolvimento de outras instituições científicas, em São Paulo, para tentar depreender da relação entre elas e o Instituto algumas hipóteses úteis para explicar sua decadência.

\section{Algumas palavras sobre os institutos anti-rábicos brasileiros}

A descoberta do imunizante anti-rábico foi o primeiro resultado, de grande repercussão, dos trabalhos de Pasteur no campo da microbiologia aplicada à medicina. Em julho de 1885, ele aplicou pela primeira vez num ser humano uma vacina baseada em suas pesquisas sobre a atenuação da virulência dos microorganismos. Além de possibilitar o tratamento preventivo da raiva - mal até hoje incurável - , sua experiência inaugurou a possibilidade de elaboração de novos profiláticos específicos para outras doenças humanas.

Em março de 1886, ao comunicar a seus colegas da Academia de Ciências de Paris os resultados obtidos com a vacina, o próprio Pasteur indicou a necessidade de criação de um estabelecimento especial para a sua produção e aplicação. A Academia encarregou-se de transformar este desejo em realidade, organizando uma subscrição pública internacional para que fosse criado um instituto anti-rábico a ser presidido por Pasteur.

Dois anos depois foi inaugurado o Instituto Pasteur de Paris. A celebridade alcançada por seu fundador e a consagração científica dos trabalhos efetuados por seus discípulos logo impulsionariam a abertura de novas subscriçōes em favor do Instituto. Em um curto espaço de tempo, a instituição transformou-se em um grande centro de pesquisas biomédicas. 
Em 12 de maio de 1886, ou seja, menos de um ano após a realização da primeira vacinação contra a raiva, o governo imperial brasileiro, em consórcio com a Santa Casa da Misericórdia do Rio de Janeiro, encarregou o Dr. Augusto Ferreira dos Santos de ir à França para adquirir a experiência necessária à introdução da vacina anti-rábica no país.

Nosso primeiro Instituto Pasteur foi inaugurado em 25 de fevereiro de 1888 - antes mesmo da inauguração do Instituto parisiense - vinculado à Santa Casa. O Brazil Médico, na época o principal periódico de medicina, congratulou-se com a iniciativa, pelo fato de ter sido instalado em suas dependências um completo laboratório de bacteriologia. Os redatores do periódico estavam convencidos de que a iniciativa tinha em mira criar uma instituição nos moldes do seu homônimo francês, apta a desenvolver pesquisas diversificadas e originais neste novo campo das ciências médicas. ${ }^{1}$ Entretanto, a similaridade entre as instituições não ultrapassava o fato de terem o mesmo nome, pois tanto no que concerne a seus objetivos como a sua organização, seus caminhos foram extremamente diversos.

Embora contasse com instalações adequadas à pesquisa bacteriológica e estivesse previsto em seu regulamento que seu corpo técnico poderia empreender investigaçōes relativas a outras entidades mórbidas, os três médicos designados para trabalhar no instituto, constantemente ocupados com a rotina da produção e aplicação do imunizante anti-rábico, não tinham como se deter em pesquisas científicas mais ambiciosas. Por outro lado, a subordinação do instituto carioca à Santa Casa da Misericórdia, e não à Faculdade de Medicina do Rio de Janeiro, demonstra seu caráter mais clínico que científico. Sendo seu objetivo central o atendimento aos atingidos por animais raivosos, nada mais natural que a entidade permanecesse subordinada à Santa Casa da Misericórdia, principal instituição do período a fazer o atendimento médico gratuito à população carente.

Quando da fundação do Instituto Pasteur do Rio de Janeiro, foi previsto que o Governo Federal contribuiria anualmente com 10:000\$000 para a sua manutenção. Em poucos anos esta cifra foi reduzida à metade, restringindo-se a 4:000\$000 em 1922. Tal quantia cobria, no período, apenas $1 / 5$

1. "Fazemos votos para que este grande laboratório (...) nāo se limite simplesmente ao fim humanitário; (...) esperamos que ele sirva para investigaçōes científicas e aprendizagem dos que quiserem cooperar para o engrandecimento da medicina brasileira. Já que nāo se poupou despesas para montar conjuntamente um moderno laboratório de bacteriologia, parece-nos lógico, nảo ser intençāo sua (da Sta. Casa) acastelar-se no estreito círculo de uma caridade egoísta, oferecendo apenas à aprendizagem e as investigaçōes especulativas. Nesse particular ainda fazemos votos para que o Instituto Pasteur do Rio de Janeiro tenha uma vida mais próspera e mais fecunda que a do laboratório de bacteriologia da Faculdade de Medicina." (O Brazil Médico, 1888:65). 
da despesa da Santa Casa com sua manutenção. ${ }^{2}$ A questão financeira pode, assim, ser invocada como um fator suplementar que explica por que o instituto carioca se restringiu à preparação e aplicação da vacina anti-rábica, sem em momento algum haver constituído um pólo de irradiação da pesquisa científica na capital e no país.

Ainda no final do século XIX, foi fundado no estado de Pernambuco um outro instituto anti-rábico com a denominação de Instituto Pasteur. Dirigido pelo médico Rodolfo Galvão, que havia se especializado em microbiologia no Instituto Pasteur de Paris, esta instituição também funcionou basicamente como posto médico, para o tratamento preventivo dos acometidos por animais hidrófobos. ${ }^{3}$ Em 1908, a Liga Mineira Contra a Tuberculose criaria um instituto Pasteur na cidade de Juiz de Fora. Este tinha como finalidade "proporcionar aos que sofrerem ou forem suspeitos de ter sofrido o contágio da hidrofobia, o tratamento preventivo; preparar a linfa vacínica antivariólica, vacinar e fornecer a vacina." ${ }^{4}$ Quatro anos mais tarde, em virtude do surgimento de uma epidemia de raiva em Santa Catarina, o governo federal fundaria mais uma instituição denominada Instituto Pasteur, com a finalidade única de preparar e aplicar o imunizante anti-rábico nessa região. ${ }^{5}$

As linhas precedentes deixam claro que a denominação Instituto Pasteur assumiu um significado diferente do original nas instituições fundadas em nossa terra. O médico Agostinho José de Souza Lima compreendeu bem esta variação semântica ao escrever sobre a história da medicina no Brasil, em 1900. “Em homenagem a uma das glórias deste sábio investigador [Pasteur] assim se tem denominado entre nós estabelecimentos exclusivamente consagrados às aplicações anti-rábicas, segundo o método de sua descoberta, e não em geral aos trabalhos experimentais a que se liga o seu nome, como se poderia legitimamente pensar, de conformidade com o espírito que presidiu a organização e fins do Instituto modelo, que em Paris tem o mesmo rótulo, e onde se estuda e se pratica bacteriologia, em pesquisas complexas sobre a causa de todas as moléstias infecciosas e meios de preveni-las e curá-las." ${ }^{6}$

Embora não seja o objetivo deste texto estender a análise às questões que se relacionam ao conjunto de instituições anti-rábicas criadas no país,

2. SANTA CASA DA MISERICORDIA DO RIO DE JANEIRO.Noticias dos diversos estabelecimentos mantidos pela Santa Casa da Misericórida. Rio de Janeiro, Typografia do Jornal do Commercio, 1909.

3. LIMA, Agostinho José de Souza. "Das ciências médicas e farmacêuticas desde o ano de 1808 até fim de 1899". In: Livro de Centenário. Rio de Janeiro, Imprensa Nacional, 1900, vol. 2, p. 122.

4. INSTITUTO PASTEUR DE JUIZ DE FORA. Regulamento do Instituto Pasteur de Juiz de Fora: anti-rábico e vacinogênico. Juiz de Fora: Typografia Brasil, 1808, p. 5.

5. Ver a esse respeito: BENCHIMOL, Jaime (coord.). Manguinhos do sonho à vida: a ciência na Belle Époque. Rio de Janeiro, Fiocruz/COC, 1990.

6. LIMA A., op. cit, p. 120. 
é importante indicar alguns dos parâmetros que nortearão esta análise em etapas subseqüentes da pesquisa.

A primeira vista, os únicos denominadores comuns a essas instituiçōes são a utilização do nome Instituto Pasteur e a fabricação da vacina anti-rábica. Isto nos remete a uma dimensão simbólica da revolução pasteuriana, que atribui um sentido mítico e fundador a Pasteur e que historicamente está alicerçada em sua primeira descoberta no campo da medicina humana. Como precursores do processo mais geral de institucionalização da medicina pasteuriana no Brasil, os Institutos Pasteur nacionais exerceram, por algum tempo, a função de emblemas do desenvolvimento de uma nova medicina enfim alçada ao grau de cientificidade e empenhada em romper laços com um passado considerado pré-científico e improfícuo pelos porta-vozes de seus discurso. Mas esta prerrogativa acabaria sendo outorgada a outras instituiçōes - em particular, o Instituto de Manguinhos - e outros personagens que expulsariam da historiografia médica brasileira as gerações e experiências precedentes.

A dimensão simbólica apresentada acima foi, também, uma componente importante no processo de modernização que transcorria em nossas cidades na virada do século. A disseminação de réplicas do Instituto Pasteur denotaria o avanço da civilização do país, para as elites urbanas, que entendiam modernização como assimilação de valores, hábitos, indumentárias e fachadas, como criação, enfim, de cenários importados do velho continente.

Nesta chave de análise caberia investigar em que medida a dimensão simbólica funcionou como moeda de troca para que os grupos efetivamente interessados em criar espaços para um novo tipo de prática profissional negociassem sua legitimidade e aceitação junto à opiniāo pública e aos grupos que detinham o controle dos recursos materiais e políticos necessários para viabilizar este projeto.

Por outro lado, cada uma destas instituições foi criada em contextos extremamente variados no que tange à realidade social e ao estágio de desenvolvimento dos saberes microbiológicos. Neste sentido, as observações genéricas de caráter comparativo, só se tornarão realmente profícuas quando combinadas à recuperação do contexto sociopolítico e científico em que estava inserida cada instituição.

\section{As instituições bacteriológicas em São Paulo}

As últimas décadas do século passado marcam um período de grande desenvolvimento em algumas áreas da Região Sudeste. No Rio de Janeiro 
observa-se uma acelerada expansāo urbana, relacionada à sua posição de capital do Império e, em seguida, da República, o que a tornava o centro cultural, político e econômico do país. Em São Paulo, o desenvolvimento urbano é conseqüência direta da expansão da lavoura cafeeira e da vinda de um grande contingente de imigrantes para o trabalho agrícola.

Iniciada na região do Vale do Paraíba, a cafeicultura ultrapassou os limites das terras fluminenses e se enraizou em Sāo Paulo. Impossibilitados de contar com o suprimento de mão-de-obra escrava, que vinha escasseando desde o fim do tráfico negreiro em 1850, e evitando recorrer à imigraçāo interna para evitar um possível conflito com a aristocracia rural nordestina, os novos barões do café radicados no Oeste Paulista optaram por embasar sua produção em relações de trabalho baseadas na importação de mão-de-obra imigrante e assalariada.?

O emprego, em larga escala, de trabalhadores europeus, a modernização das técnicas de cultivo e a utilização das férteis terras do Oeste Paulista asseguraram um rápido desenvolvimento à agricultura cafeeira no Estado. A partir da década de 1880 , São Paulo passou a ser o principal produtor nacional. A expansão dos cafezais foi acompanhada pelo surgimento de uma extensa malha ferroviária para o escoamento da produção. Esta, ao mesmo tempo que alcançava novas terras, aumentando o perímetro dos cafezais, diminuía os custos da produção. Como conseqüência surgiram novas cidades que, rapidamente, sofreram grande expansão demográfica, em virtude do elevado número de imigrantes trazidos para as lavouras.

A capital paulista não ficou imune a esse processo. A acanhada aldeia do início do século adquiriu novas funções comerciais e financeiras e transformou-se no espaço prioritário de obtenção de mão-de-obra e capitais para os novos empreendimentos. Se até a metade do século passado sua população não passava de 20.000 habitantes, no alvorecer deste século já atingia a cifra de $240.000 .^{8}$ Aos poucos a cidade adquiriu novas feiçōes, passando a contar com iluminação pública, ruas pavimentadas e bondes de tração animal. Logo os barões do café começaram a se transferir para a capital, passando a residir em chácaras e em novos bairros em formação. Ao mesmo tempo, o dinheiro oriundo da cafeicultura fazia proliferar indústrias e incentivava, também, a transferência para a cidade de imigrantes, descontentes com as condiçōes de vida no campo.

7. Em relaçăo as conjunçōes políticas que culminaram com a decisāo de importação massiva de imigrantes para as lavouras de café ver: REIS, Eliza Pereira. "Elites agrárias, state-building e autoritarismo". Dados: revista de Cièncias Sociais. Rio de Janeiro, vol. 25, nº 253, 1982 pp. 331-348.

8. COSTA, Emília Viotti da. Da Monarquia à República: momentos decisivos. Sāo Paulo, Brasiliense, 1985, p. 211. 
Como em outras regiōes, o crescimento populacional da cidade nāo se fez acompanhar da expansāo de equipamentos e serviços urbanos que possibilitassem a melhoria do nível de vida e saúde de grande parte da população. À medida que se ampliava o processo imigratório, surgiam novas epidemias e elevavam-se os índices de doenças muitas vezes desconhecidas que eram atribuídas aos imigrantes. Este processo também ocorreu nas áreas rurais. Desde 1850 , Santos, a porta de entrada dos imigrantes, era constantemente assolada por epidemias de febre amarela. Entre 1889 e 1892 irromperam surtos da doença em Campinas, Rio Claro e outras cidades do interior paulista. ${ }^{9}$

As condiçōes sanitárias reinantes nas zonas urbanas e rurais ameaçavam a manutençāo do desenvolvimento econômico baseado na importação de mão-de-obra. Segundo Castro Santos, "as elites paulistas - particularmente os fazendeiros ávidos por māo-de-obra - apostaram tudo no sucesso do programa de imigração. Qualquer obstáculo à vinda de trabalhadores europeus tornava-se motivo de alarme para os fazendeiros, pois temiam que a busca de imigrantes fosse interrompida se o estado ganhasse uma reputaçāo de insalubridade. Nesse sentido, as questões de reforma de saúde pública - considerando-se o saneamento como único meio de assegurar a contínua afluência de imigrantes - tornaram-se uma preocupação central para as elites dominantes." 10

Nesse contexto, o estado de Sāo Paulo tomou as primeiras iniciativas no sentido de dar soluções aos problemas sanitários. Ainda no Império, os programas da Inspetoria de Higiene passaram a ser financiados por verbas destinadas à imigração. Mas foi no regime federativo, implantado com a República, que o governo paulista tomou as rédeas da organização e custeio de suas agências de saúde pública.

Em 1892, o vice-presidente de São Paulo, Cerqueira Cesar, reestruturou os serviços de saúde paulistas. Com a reforma, o estado passou a se responsabilizar pela assistência financeira aos serviços de saúde das cidades interioranas e a centralizar, na Diretoria de Higiene, as funçōes relativas à saúde pública. Em consequiência dessa reorganização, foram criados quatro laboratórios: o Bacteriológico, o Vacinogênico, o de Análises Químicas e o Farmacêutico. Estes tinham por finalidades diagnosticar doenças epidêmicas, produzir imunizantes e terapêuticos e analisar os

9. Os dados sobre as condiçōes sanitárias do estado de Sāo Paulo, nesse período, encontram-se em: MORSE, Richard M. Formaçāo histórica de São Paulo. Sāo Paulo, Difusāo Européia do Livro, 1970, p. 247.

10. CASTRO SANTOS, Luiz Antônio de. "Power ideology and public health 1889-1930". Cambridge, Harvard Univesity, 1987, p.164, mimeo. 
alimentos vendidos no varejo. Segundo Mascarenhas, "o Serviço Sanitário, criado em 1892, era uma reuniāo de laboratórios de saúde pública em torno de uma diretoria de Higiene, com um corpo de delegados de higiene encarregados do combate às epidemias, saneamento do meio físico, polícia da alimentação e fiscalizaçāo das profissões médicas e afins." 11

Desses laboratórios, somente o Bacteriológico apresentou um desenvolvimento significativo, transformando-se no principal esteio do Serviço Sanitário no diagnóstico e profilaxia de diversas doenças muitas vezes desconhecidas pelos clínicos da capital. Sua atribuição principal eram os estudos microscópicos e bacteriológicos para respaldar os diagnósticos clínicos e esclarecer a etiologia das epidemias, endemias e epizootias mais freqüentes no Estado. Sempre que possível procederia ao preparo e aplicação de vacinas e soluçōes terapêuticas. ${ }^{12}$

Seu primeiro diretor foi Felix le Dantec, bacteriologista francês indicado pelo próprio Pasteur para presidir a instituição. Entretanto, sua permanência no instituto foi bastante curta, sendo substituído por Adolpho Lutz em poucos meses.

Nomeado para o cargo de 1893, foi Adolpho Lutz que impulsionou e viabilizou a instituição. Junto com três auxiliares, especialmente Vital Brasil, que ingressou em 1897, Lutz realizou investigações sobre as doenças infecciosas que grassavam endêmica ou epidemicamente no estado, estabelecendo diagnósticos que escapavam à percepção dos clínicos e que suscitaram duras controvérsias com eles. O repertório de estudos, em laboratório ou em campo, realizados no Instituto incluía várias doenças humanas e animais, perpassando todos os objetos de preocupaçāo imediata da saúde pública. ${ }^{13}$

A lei que reorganizaou o serviço sanitário do Estado, em 1896, retirou de suas atribuições o preparo de vacinas e outras aplicações terapêuticas, dedicando-se o Instituto à rotina dos exames bacteriológicos e anatomopatológicos, solicitados pelos poderes públicos ou por particulares. A impossibilidade de executar um projeto consistente de pesquisa - devido, em grande parte, ao atrelamento do instituto às demandas práticas imediatas da

11. MASCARENHAS, R. S. "Contribuição para o estudo da administração sanitária em São Paulo". Tese de livre docência da Faculdade de Higiene e Saúde Pública da USP. Sāo Paulo, 1949, p. 42, mimeo. 12. Idem.

13. Em relação à história do Instituto Bacteriológico de São Paulo, ver: BENCHIMOL, J. (op. cit); CASTRO SANTOS, (op. cit); CAMARGO, Ana Maria Faccioli de. "Os impasses da pesquisa microbiológica e as políticas de saúde pública em São Paulo (1892 a 1934)". Dissertação de mestrado, Campinas, Universidade Estadual de Campinas, Faculdade de Educação 1984, mimeo e STEPAN, Nancy. Gênese e evoluçāo da ciência brasileira: Oswaldo Cruz e a política de investigação cientifica e médica. Rio de Janeiro, Ed. Artenova, 1976. 
política sanitária - fizeram com que Lutz deixasse a direção do Bacteriológico em 1908, transferindo-se para o Instituto Oswaldo Cruz, no Rio de Janeiro. A partir desse período o Bacteriológico mergulhou em sucessivas crises, determinadas pela falta de pessoal qualificado e de equipamentos adequados para o desenvolvimento dos trabalhos científicos.

Sob o impacto de uma conjuntura emergencial deflagrada pelo aparecimento da peste bubônica no porto de Santos, em 1899, foi criado o Instituto Serunterápico de São Paulo. Instalado na Fazenda Butantan, como dependência do Instituto Bacteriológico, teve sua direção confiada a Vital Brasil. Imediatamente após sua fundação, o laboratório iniciou a fabricação das primeiras partidas de soro e vacina antipestosos, incorporando rapidamente outros imunoterápicos demandados pela saúde pública.

Em 1901, o Butantan foi desmembrado do Instituto Bacteriológico, passando a funcionar como instituição autônoma. Nesse momento, embora ainda funcionasse em toscas instalações e contasse com pequeno número de equipamentos, começou a produzir, experimentalmente, as primeiras doses de soro antiofídico e deu início às pesquisas sobre a febre tifóide e o soro anti-rábico; em 1903, passou a enviar soro antiofídico para alguns estados da federação; em 1906 iniciou a preparação do soro antidiftérico e, no ano seguinte, da tuberculina para o diagnóstico da tuberculose humana. ${ }^{14}$

Sem deixar de lado a produção e pesquisa em campos diversos, o Butantan especializou-se nas investigaçōes relacionadas ao ofidismo e na produção de soros para esse fim. A partir de 1914, teve seu quadro de pessoal ampliado e passou a funcionar em novas instalações, o que the permitiu intensificar seus trabalhos de produçāo e pesquisa e se consolidar como instituição de pesquisa na área da saúde pública.

Os autores que estudaram a saúde pública e as instituições científicas paulistas enfatizam, com freqüência, a relevância do Serviço Sanitário na melhoria das condições de saúde do Estado. Segundo Nancy Stepan, "Lutz, juntamente com o Dr. Emílio Ribas, que se tornara diretor dos serviços sanitários do Estado em 1898, foi responsável pela grande melhoria da saúde pública em São Paulo. Numa ocasião em que a população crescia num ritmo sem precedentes, o coeficiente de mortalidade da cidade de São Paulo foi reduzido de 30,73 em 1894, para 28,27 em 1895, 31,13 em 1896,24,86 em 1897, 21,27 em 1898, e 18,14 em 1899. Antes de 1890, o coeficiente de mortalidade crescera constantemente." 15 Castro Santos,

14. Os dados sobre o Instituto Butantan encontram-se nas obras citadas na nota anterior e, mais especificamente, em: OLIVEIRA, Jandira de. "Cronologia do Instituto Butantan." Memórias do Instituto Butantan. Sāo Paulo, 44/45:11-79, 1980-81

15. STEPAN N., op. cit., p. 132. 
citando o estudo de Blount, assevera que "entre 1889 e 1930 o estado sulista construiu o mais amplo serviço regional de saneamento e higiene do Brasil e talvez de toda a América do Sul. Além da superioridade do estado na administração de saúde pública e na criação de instituições científicas, os dados demográficos (muito insuficientes) indicam que o estado também esteve à frente na redução da mortalidade em relação ao país como um todo." 16

O papel desempenhado pelos institutos bacteriológicos oficiais constitui um elemento importante para compreender o processo de criação do Instituto Pasteur de São Paulo. Acreditamos que as contribuições daqueles institutos à saúde pública, através da utilização de conhecimentos microbiológicos, estimularam os médicos envolvidos na criação do instituto anti-rábico paulista. Além disso, foram importantes para a formação da massa crítica que iria impulsionar o programa de pesquisas do Instituto Pasteur. Pesquisadores como Ivo Bandi, que pertencia ao Bacteriológico, e Arnaldo Vieira de Carvalho, diretor do Vacinogênico, levariam para o Instituto Pasteur a experiência adquirida nos trabalhos realizados nos laboratórios oficiais.

No entanto, seria enganoso imaginar que a criação do Instituto Pasteur de São Paulo é uma decorrência natural do desenvolvimento das instituições oficiais. A observação histórica nos mostra que, em 1903, momento em que aflora a idéia de se criar um instituto anti-rábico, grande parte das pesquisas bacteriológicas desenvolvidas naquelas instituições não tinha total aceitação no meio médico. ${ }^{17}$ Por outro lado, nesse período, os institutos oficiais eram ainda apostas incertas no que concerne às expectativas de seus quadros de maior projeção quanto a amplitude e ao papel que deveria ter a pesquisa biomédica. Institutições de pequeno porte - em 1903 o Instituto Bacteriológico contava com apenas quatro técnicos, e o Butantan, funcionando em instalaçōes precárias, só com dois -, seu destino dependia de complicadas negociações com os interesses imediatistas do estado em relação à saúde pública. Neste sentido, a criação do Instituto Pasteur de São Paulo poderia até constituir, na perspectiva de seus promotores, uma alternativa aos limites estreitos de uma organização

16. CASTRO SANTOS, op. cit., p. 159-160 e BLOUNT J., "The public health movement in Saa Paulo: a history of the sanitary service: 1892-1918. Tulane University,.1971, p. 14, mimeo.

17. Exemplo da discordância manifestada pelos clínicos se naâo aos conhecimentos microbiológicos em si com certeza à interpretaçāo e ap licaçâo destes, é a forte oposiçâo suscitada pelas práticas de desinfecçāo e vacinaçâo levadas a cabo, nesse período, por Oswaldo Cruz, no Rio de Janeiro. As experiências de Emílio Ribas sobre a forma de disseminação da febre amarela também sofreram violentas críticas dos médicos paulistas. 
estatal. Teria melhores chances de se converter numa instituição de medicina experimental análoga ao Instituto Pasteur de Paris, se optasse, desde o princípio, por seguir um caminho independente do estado, com auto-suficiência para atuar no campo da pesquisa biomédica, do ensino da microbiologia, da produção de imunizantes e no tratamento anti-rábico.

\section{A criação do Instituto Pasteur de São Paulo}

"À população do Estado de São Paulo a comissão organizadora do Instituto Pasteur dirige um caloroso apelo para que todos, ricos e pobres, a exemplo do que se tem feito no estrangeiro, contribuam, no limite das suas posses, para a fundação deste estabelecimento destinado a prestar os mais relevantes serviços, tanto do ponto de vista científico, como do ponto de vista humanitário. Que todas as virtudes, como pedia Pasteur em França, se cotizem para a instalação desta oficina de trabalho, que será ao mesmo tempo um instituto de caridade e ciência" (O Estado de São Paulo, 25/08/1903, p. 2).

A idéia de se criar um instituto anti-rábico no estado de São Paulo antecedeu em alguns anos o surgimento do Instituto Pasteur. A lei $n^{\circledR} 345$, de 13 de agosto de 1895 , autorizava o governo paulista a criar um instituto para o tratamento da raiva e da difteria. No ano seguinte, uma nova lei (de 17 de fevereiro) declarou de utilidade pública alguns terrenos da capital, destinando-os à implantação do Instituto Pasteur e Roux. ${ }^{18}$ Entretanto, sua criação não se concretizou. Somente no século seguinte, pelas mãos da iniciativa privada, o estado de São Paulo teria seu instituto anti-rábico.

No primeiro semestre de 1903, Ulysses Paranhos, jovem médico do Serviço de Bacteriologia do Hospital Geral da Santa Casa, retomou a idéia de fundar um Instituto anti-rábico na capital do Estado. Para tanto reuniuse aos Drs. Bittencourt Rodrigues, clínico português aqui exilado por motivos políticos, Vuonno Netto e Azurem Furtado, formando uma comissão para a organização da instituição. Seus primeiros passos consistiram em convencer personalidades da sociedade paulistana e reputados médicos da cidade a tomarem parte do empreendimento, que teria caráter filantrópico.

Em 5 de agosto de 1903, foi fundado o Instituto Pasteur de São Paulo, provisoriamente instalado no consultório do Dr. Bittencourt Rodrigues. ${ }^{19}$

18. Cf. MASCARENHAS R. S., op. cit., p. 54.

19. As informaçōes que se seguem constam dos estatutos do Instituto Pasteur de Sâo Paulo, publicados pelo jornal O Estado de S. Paulo, em 13 de outubro de 1903. 
Seus estatutos, aprovados em outubro, o definiam como instituição de caráter privado, com objetivos científicos e humanitários, organizada nos padrōes dos institutos congêneres existentes no estrangeiro. Para presidilo, foi eleito o ex-deputado e diretor da Superintendência de Obras Públicas do Estado, Ignácio Wallace da Gama Cochrane. ${ }^{20}$ Como diretor dos serviços técnicos foi contratado Ivo Bandi, ex-professor de higiene e bacteriologia da Faculdade de Medicina de Bolonha e pesquisador do Instituto Bacteriológico. ${ }^{21}$

O Instituto era composto, inicialmente, por dezesseis membros efetivos. Seis destes, "escolhidos dentre as pessoas que maiores serviços tenham prestado ao Instituto, para a sua fundação ou manutenção", faziam parte da seção administrativa. Os outros dez integrantes, "escolhidos pela sua competência profissional como médicos ou pelo seu valor científico em qualquer ramo das ciências biológicas”, formava a seção de medicina e biologia. As duas seçōes reunidas constituíam a comissão permanente do Instituto, responsável pela eleição de seu conselho diretor. Este se compunha do presidente, vice, dois secretários e um tesoureiro, eleitos a cada dois anos para cumprir suas funções de forma gratuita.

A Seção de Medicina e Biologia foi composta pelos Drs. Ivo Bandi, Ulysses Paranhos, Alberto Seabra, Arnaldo Vieira de Carvalho, Antonio Bittencourt Rodrigues, J. J. Nova, Mathias Valadão, Paulo Bourroul, Roberto Höettinger, Sergio Meira e Azurem Furtado. Este último, transferiu-se em 1905 para o Instituto Bromatológico Municipal do Rio de Janeiro, sendo substituído pelo Dr. Diogo de Faria. A Seção Administrativa foi formada pelo desembargador José Maria do Valle; Srs. Ignácio Cochrane da Gama, Francisco Matarazzo e Guilhermne de Andrade Villares; Drs. Victor Freire e Vuono Netto. O Conselho Diretor tinha como integrantes Ignácio Cochrane da Gama, presidente; Bittencourt Rodrigues,

20. Ignácio Wallace da Gama Cochrane era descendente do lorde Cochrane — conhecido em nossa história por sua atuaçâo nos episódios relativos à independência. Enteado de Thomas Cochrane, criador da primeira linha de bondes do Rio de Janeiro e reputado médico homeopata, Ignácio Cochrane trabalhou como engenheiro ferroviário na implantaçẩo das primeiras ferrovias do interior do país, foi empresário exportador de café e parlamentar durante o Império. Ocupou os cargos de vereador pela cidade de Santos (1864-1867), deputado da província de Sâo Paulo (1870-1879) e deputado à Assembléia Geral, indicado por São Paulo (1885-1890), atuando sempre no Partido Conservador. Afastou-se da política com a Proclamação da República, por defender radicalmente regime monarquista. (Cf. AZEVEDO, 1965).

21. Além dos trabalhos rotineiros executados no Instituto Bacteriológico, lvo Bandi destacou-se como colaborador de Emílio Ribas e Adolpho Lutz nas pesquisas sobre a febre amarela, executadas entre 1902 e o início de 1903 pelo Serviço Sanitário em colaboraçăo com o Instituto Bacteriológico, para comprovar a teoria culicidiana da doença. 
vice; Alberto Seabra e J. J. Nova, secretários e o desembargador José Maria do Valle, tesoureiro.

Uma primeira observação nos leva a crer que parte dos pesquisadores que vieram a integrar a seção de medicina e biologia do Instituto pertenciam a um seleto grupo de médicos afinados com a medicina bacteriológica e participantes dos principais fóruns de associação médica do período. Além de seu diretor, pesquisadores como Ulysses Paranhos e Arnaldo Vieira de Carvalho eram assíduos colaborares da Revista Médica de São Paulo, ${ }^{22}$ sendo que Ulysses Paranhos ocupava, ainda, o cargo de secretário da Sociedade de Medicina e Cirurgia de São Paulo.

Os estatutos do Instituto indicavam três áreas de atuação: a produção de imunobiológicos, o ensino da bacteriologia e a pesquisa biomédica em áreas que apresentassem interesse de aplicação em saúde pública.

Os fundos para a criação dos laboratórios foram conseguidos através de subscrições públicas. Para a manutenção da institutição previam-se três fontes diferentes de rendas: a venda de produtos biológicos, exames anatomopatológicos e análises químicas e bacteriológicas; as subvençōes públicas e particulares e as taxas de matrículas e diplomas dos cursos de bacteriologia.

Além da preparaçāo da vacina anti-rábica e do tratamento preventivo, gratuito, da doença, os estatutos indicavam a produção dos soros antidiftéricos, antipestoso, antitetânico e anticarbunculoso; das vacinas anticarbunculosa e anti-rábica; da tuberculina e maleina, ambas destinadas ao exame do gado, e de outras substâncias biológicas "já consagradas pela ciência e relevantes para a saúde pública e para a veterinária”.

Com exceção do soro antipestoso, fabricado no Butantan e no Instituto de Manguinhos, e da vacina anti-rábica, produzida nos Instituto Pasteur do Rio de Janeiro e de Recife, nenhum dos produtos cogitados pelo Instituto eram elaborados por instituições nacionais no período. Ainda não dispomos de fontes que nos permitam avaliar, com precisão, os níveis de demanda para estes imunizantes. Talvez fossem importados. Sabemos, somente, que a vacina antipestosa era vendida pelo Butantan à Diretoria Geral de Saúde Pública do Rio de Janeiro, e para evitar a concorrência

22. A Revista Médica de São Paulo foi o primeiro periódico médico do estado. Criada em 1898, pelos Drs. Victor Godinho e Arthur Mendonça, com o objetivo de difundir as novas conquistas da medicina que de alguma maneira estivessem relacionadas à aplicaçāo prática. (REVISTA MÉDICA DE SĀO PAULO, 1898:1 - editorial). Nos anos que se seguiram, a revista começou a dar grande espaço aos estudos microbiológicos, abrigando as polêmicas sobre os trabalhos relativos à febre amarela, os relatórios dos institutos microbiológicos e bacteriologia" escritas pelo Dr. Bonilha de Toledo. 
com a instituição oficial, o Serviço Sanitário proibiu a fabricação da vacina no Instituto Pasteur.

No campo de ensino médico, os estatutos consignavam a manutenção provisória de cursos de bacteriologia geral, técnica bacteriológica e bacteriologia e microscopia aplicadas à clínica $\mathrm{e}$ à higiene. A intenção era que esses cursos fossem os precursores de uma faculdade de higiene a ser fundada pelo Instituto. Tal preocupaçāo derivava da inexistência de uma faculdade de medicina no Estado. Entretanto, a intenção não se concretizou. Só em 1918, com o apoio da Fundação Rockefeller, São Paulo teria um laboratório de higiene, agregado à Faculdade de Medicina que fora fundada em 1912.

$\mathrm{Na}$ área de pesquisa, o Instituto propunha-se a estudar as moléstias tropicais, em particular aquelas que reinavam endêmica ou epidemicamente no estado de São Paulo. Objetivava ainda a publicação de uma revista trimestral para divulgação de seus trabalhos científicos e a fundação de filiais em outros pontos do estado, "sempre que fosse possível ou necessário".

A estrutura formal do Instituto Pasteur de São Paulo nos remete, obrigatoriamente, ao Instituto Pasteur de Paris. A semelhança entre a forma de organização dos dois evidencia a influência da instituição parisiense na concepção que presidiu a criação do instituto paulista. ${ }^{23}$

\section{Os dois Pasteur}

A literatura que aborda aspectos relacionados ao Instituto Pasteur de Paris destaca sua originalidade no cenário científico europeu. Esta se revela no direcionamento de suas pesquisas para a resolução do problema da saúde pública e na criação de um modelo institucional com larga autonomia administrativa e financeira, embasado em três áreas de atividades: a pesquisa, a produçāo de imunobiológicos e o ensino da bacteriologia. ${ }^{24}$

23. Seus estudos explicitam essa influência ao afirmarem que: "O Instituto Pasteur de São Paulo quanto a seus fins e organizaçāo científica, procurará quanto possível, modelar-se pelo tipo de outros institutos congêneres existentes no estrangeiro e com os quais se esforçará para manter as mais estreitas relaçōes" (ESTATUTOS DO INSTITUTO PASTEUR DE SĀO PAULO, 1903). As declaraçōes de seus diretores, veiculadas pela imprensa paulista, săo ainda mais específicas, assegurando que o Instituto tinha como objetivo seguir os passos da instituiçảo dirigida por Pasteur (Cf. O Estado de São Paulo, 1903).

24. Para um melhor conhecimento da história do Instituto Pasteur de Paris ver: BAYET, Claire Salomon (org.) Pasteur et la revolution pastoriene. Paris, Payot, 1986. Algumas comparaçōes entre esta instituiçāo e os institutos biomédicos nacionais encontram-se em: BENCHIMOL, J. (op. cit.) e STEPAN, N. (op. cit.). 
Como vimos, o tripé ensino, pesquisa e produção eram a base da organização do Instituto Pasteur de São Paulo. A comercialização de seus produtos médicos veterinários e as dotações governamentais e privadas deveriam subsidiar um programa anti-rábico e pesquisas em diversos setores que tivessem interesse de aplicação imediata; o ensino da bacteriologia viria suprir a necessidade de formação de quadros nessa nova disciplina. $O$ projeto de ter na produção de imunobiológicos uma fonte de renda também é semelhante ao do instituto francês. Este, embora recebesse subvençōes dos min istérios da Instrução e da Agricultura da França, arrecadava de doações e da venda de seus produtos a maior parte de suas rendas.

Observamos, também, a similaridade entre as duas instituiçōes no plano das relações que mantinham com o Estado. O Instituto Pasteur de Paris era uma entidade privada, considerada pelo governo francês como de utilidade pública. Essa condiçāo the garantia ao mesmo tempo uma grande autonomia e a possibilidade de contar com subvençōes oficiais para sua manutenção. O instituto paulista gozava do mesmo estatuto, auferia rendas do governo federal, estadual e de Câmaras Municipais, mantendo, entretanto, autonomia tanto na administraçāo de suas pesquisas, como na escolha de seus dirigentes.

Os parágrafos precedentes têm a intenção limitada de apresentar algumas semelhanças formais entre os Institutos Pasteur de Paris e de São Paulo. Pois o que em 1903 não passava de um projeto em São Paulo, na França representava o desdobramento de um longo processo científico e social que culminou com a cristalizaçāo de um modelo institucional.

Quando foi fundado o instituto paulista, seu congênere francês já havia passado por grandes transformaçōes. Ao ser inaugurado, este contava apenas com cinco laboratórios e um pessoal técnico composto de cerca de vinte pessoas. Em 1903, já mantinha um hospital para o estudo de doenças infecciosas, publicava um periódico científico de circulação internacional e contava com filiais em Saigon, Nha Trang (costa do Anam) e Hanói. Grande parte das pesquisas elaboradas em seus laboratórios redundavam em importantes contribuiçóes para a saúde coletiva. Entre suas maiores conquistas figuravam a descoberta do modo de atuação do bacilo diftérico (Roux e Yersin, 1888); a descoberta do tratamento da difteria e o desenvolvimento da soroterapia (Roux, Martin e Chaillou, 1894); os primeiros trabalhos sobre fagocitose e inflamação (Metchnikoff, 1888/1900) e a identificação do bacilo da peste (Yersin, 1894). ${ }^{25}$

25. Estas informaçöes se encontram na brochura Institut Pasteur 1887, 1987, 2087; un nouveau siècle. Documento produzido para a exposiçāo comemorativa do centenário do Instituto Pasteur, Paris, 1987. 
Na virada do século, outras instituições biomédicas brasileiras o tomariam como modelo de organização. $O$ pasteuriano Le Dantec foi contratado para recriar em São Paulo uma instituição naqueles moldes. Como sabemos, Oswaldo Cruz propôs em 1903 ao Congresso, quando este debatia a reforma dos serviços sanitários da União, que o Instituto Soroterápico Federal “(...) fosse transformado num instituto para o estudo das doenças infecciosas tropicais, seguindo as linhas do Instituto Pasteur de Paris”. ${ }^{26}$

Para os fundadores do Instituto Pasteur de São Paulo, o modelo da instituição parisiense mostrava-se particularmente sedutor, por sua abrangência e capacidade de auto-sustentação. A possibilidade de atuação em diversos campos de atividade - que, como vimos, não eram abarcados por outras instituições - abria uma perspectiva promissora para o Instituto. Além disso, ao adotarem o estatuto peculiar, de entidade filantrópica-assistencial e, ao mesmo tempo, comercial e científica, asseguravam a entrada de vários tipos de recursos - subvenções, doações e venda de produtos - que pareciam suficientes para garantir a sua manutenção.

\section{O cotidiano do Instituto Pasteur de São Paulo}

Inaugurado em agosto de 1903, o Instituto começaria, em novembro do mesmo ano, a vacinação pública. Para isso, seu diretor técnico obteve culturas do bacilo de raiva no Instituto Pasteur do Rio de Janeiro e elaborou as primeiras vacinas. Com o intuito de conseguir clientela, mandou publicar nos jornais da cidade anúncios publicitários colocando os serviços de tratamento anti-rábico à disposição da população.

A criação do Instituto foi noticiada com louvor pela imprensa paulista, pois vinha suprir a inexistência de tratamento anti-rábico na cidade. "Durante os meses de julho, agosto e a primeira quinzena de setembro, foram enviadas pela Diretoria Sanitária ao Instituto Pasteur do Rio de Janeiro 27 pessoas mordidas por cães hidrófobos. De primeiro de janeiro a 31 de agosto, só a polícia enviou ao mesmo estabelecimento 24 pessoas, e neste mês já a polícia mandou 12 indivíduos (...)” O editorialista acrescentava que muitas pessoas não eram tratadas a tempo de serem salvas devido à duração da viagem. ${ }^{27}$

A expectativa da imprensa não foi em vão. Através de um acordo com a Santa Casa da Misericórdia de São Paulo, o Instituto passou a garantir passagem e alojamento gratuito para os doentes de fora da cidade, possi-

26. STEPAN N., op. cit., p. 78.

27. O ESTADO DE S. PAULO, 30 de setembro de 1903. 
bilitando o tratamento de grande número de pessoas vindas do interior. Em menos de um ano, já havia vacinado 463 pessoas. Um número considerável, se comparado às 570 vacinações efetuadas pelo Instituto Pasteur do Rio de Janeiro no mesmo período. ${ }^{28}$

A partir da fundação do Instituto, os membros de sua comissão permanente empenharam-se na busca de fundos para a aquisição de um prédio definitivo e dos equipamentos necessários à expansão de suas atividades. Foi, então, desencadeada uma campanha para angariar donativos, feita pela imprensa e através de listas passadas aos comerciantes, industriais e personalidades da cidade. Além dos recursos auferidos com essa iniciativa, o Instituto conseguiu obter subvençōes de diversas Câmaras Municipais, de associações de classe e do estado de São Paulo.

Entre os colaboradores da primeira subscrição encontram-se grandes industriais, como Francisco Matarazzo - o maior doador individual - e Inácio Penteado; empresas privadas, como a Light and Power e o Banco Comercial de Itália, e associaçōes de classe como a Sociedade Auxiliadora das Classes Laboriosas e a Sociedade de Medicina e Cirurgia do Estado de São Paulo. O montante adquirido ascendeu à cifra de 80 contos de réis. Quantia significativa, se comparada aos 56 contos de réis destinados pelo orçamento do Estado, de 1901, para as reformas e manutenção do Instituto Soroterápico do Butantan, em virtude da sua desincorporação do Instituto Bacteriológico.

Em novembro de 1903, o Instituto adquiriu, por 40 contos de réis, um prédio na Avenida Paulista, providenciando em seguida a importação de equipamentos adequados e reformas no edifício. Em seus três andares foram distribuídas as três seçōes: anti-rábica, bacteriológica, histológica normal e patológica. Em outras dependências foram instaladas a sala para inoculações e autópsias, sala de espera, biblioteca, sala de reuniões, sala de microfotografia, de inoculaçōes anti-rábicas, gabinete dos aparelhos de esterilização, do termostato e do diretor. O prédio contava, ainda, com dois grandes laboratórios e os aposentos do diretor. ${ }^{29}$

Em 18 de fevereiro de 1904 o Instituto foi inaugurado oficialmente. Na ocasião, seu primeiro diretor técnico já havia abandonado o posto. Devido a desentendimentos com Emílio Ribas, diretor do Serviço Sanitário do Estado, motivados pela recusa deste de validar seu diploma, o Dr. Ivo

28. SANTA CASA DA MISERICÓRDIA, 1909, op. cit.

29. O detalhamento das instalaçōes do Instituto encontram-se num artigo sobre a sua fundaçāo publicado na Revista Médica de Säo Paulo $(4 ; 84,1904)$. 
Bandi teve de rescindir seu contrato. A direção foi confiada provisoriamente a Ulysses Paranhos e Azurem Furtado.

Nos anos subseqüentes à inauguração oficial, o Instituto teve grande desenvolvimento nas áreas de pesquisa, produção de imunobiológicos e de tratamento anti-rábico. Em 1904, os Drs. Roberto Höetinger e Azurem Furtado dedicaram-se ao estudo do valor do soro antiofídico no combate à raiva; este último, em conjunto com o estudante de medicina Amélio de Magalhães, preocupou-se ainda com estudos experimentais sobre a raiva; o Dr. Germano Vert realizou pesquisas sobre uma doença que atacara as plantações de batatas de São Paulo; Ulysses Paranhos se ocupava dos estudos sobre a febre amarela. Seus trabalhos seguiam os passos do bacteriologista italiano Sanarelli, que pensava ter descoberto o micróbio causador desta doença. ${ }^{30}$ Paranhos desenvolveu, também, estudos sobre a tinea imbricata, publicando trabalhos sobre o assunto no Journal of Tropical Medecine, de Londres.

Os relatórios do Instituto informam que o método empregado na vacinação anti-rábica era o mesmo seguido por Pasteur, acrescentando-se somente as modificaçōes introduzidas por Calmette. Consistia na inoculação do vírus rábico no coelho e na imediata retirada de sua medula espinhal após a morte pela infecção. A medula era suspensa em frascos de Mariotte, contendo ao fundo potassa cáustica, mantida num refrigerador a $20^{\circ} \mathrm{C}$. Com este procedimento, sua virulência era aos poucos diminuída. "Começa-se o processo de vacinação, utilizando a medula de 14 e 13 dias e chegando-se, por passagens sucessivas, a uma mistura de medulas de três e dois dias para o tratamento ordinário; e dois dias isoladamente para o tratamento intensivo. (...) A conservação do vírus fixo é obtida pela imersão da substância vacinante em glicerina neutra, como aconselha Calmette. A fiscalização da pureza da vacina é feita pelo exame microscópico e pela cultura da medula (...). A presença do germem ou a turvação do caldo implicam a rejeiçāo da medula." ${ }^{31}$

30. Giovanni Sanarelli, diretor do Instituto de Higiene de Montevidéu entre 1895 e 1898, através de experiências efetuadas nessa capital, isolou o bacilo icteróide, imaginando ser este o causador da febre amarela. A partir da apresentação de sua teoria à comunidade científica internacional, cientistas de vários países passaram a elaborar pesquisas neste campo, com a intenção de testar a veracidade de sua descoberta. Em 1900, os trabalhos de Adolpho Lutz, Terni e de pesquisadores americanos que estudavam a doença em Cuba, concluíram que o bacilo apresentado por Sanarelli era apenas um elemento acidental na doença. Entretanto, as controvérsias sobre o papel do bacilo icteróide na febre amarela permarieceram até a década de 1920, quando foram confirmadas as teorias sobre a causaçāo virótica da doença (BENCHIMOL, 1990:20).

31. INSTITUTO PASTEUR DE SÃO PAULO. Relatório anual de 1906. Săo Paulo: Augusto Siqueira e Comp., 1907. 
Os dois tipos de tratamento acima indicados (ordinário e intensivo) eram adotados de acordo com a gravidade e a localização da mordedura. O primeiro consistia em aplicações diárias num período de 21 dias; o segundo prolongava-se por 24 dias.

Os médicos responsáveis pelo serviço anti-rábico mostravam-se orgulhosos com o resultado dos tratamentos efetuados com sua vacina. "Em onze meses, apenas, de existência, o Instituto Pasteur socorreu a 463 pessoas, que vieram lhe bater às portas em procura do remédio contra a terrível hidrofobia. Destas, até a presente data, nenhuma teve o infortúnio de ver sem êxito o tratamento, fato que nos coloca em vantajosa posição diante das melhores estatísticas do mundo." ${ }^{32}$

A instituição executava, também, a vacinação contra a varíola, utilizando a vacina cedida pelo Instituto Vacinogênico, e fazia análises para elucidação de diagnósticos clínicos, atendendo a diversos médicos da capital. Aos poucos foi incorporando a produção de novos imunizantes. Já em 1905 iniciou o preparo experimental de duas vacinas de uso veterinário: a anticarbunculosa e a vacina contra o carbúnculo sintomático, doença que atingia constantemente o gado das estâncias paulistas e mineiras. O Instituto passou, também, a produzir o fermento búlgaro, substância biológica utilizada na fabricação de coalhadas de uso medicinal. Os produtos elaborados eram, em sua maior parte, vendidos aos clínicos paulistas e, quando requisitados por entidades oficiais de São Paulo, fornecidos gratuitamente. $\mathrm{Na}$ área de pesquisa, o relatório referente ao ano de $1905 \mathrm{faz}$ menção a 15 trabalhos originais.

Ainda nesse ano, o Dr. Ulysses Paranhos foi enviado para um estágio de seis meses na Europa. No Instituto Pasteur e na Faculdade de Medicina de Paris, freqüentou cursos de especialização em diversos campos da microbiologia. Ao regressar ao país, passou a se dedicar aos estudos sobre a lepra.

Em relação à administração, cabe destacar o importante trabalho desempenhado pelo seu presidente Inácio Cochrane. Graças às estreitas relações que mantinha com os representantes das ascendentes indústrias de São Paulo e com os produtores rurais das cidades interioranas, Cochrane conseguiu obter expressivas doaçōes para o Instituto. Através de requintados relatórios, que eram enviados a instituições científicas nacionais e estrangeiras e a possíveis colaboradores, e de artigos publicados em

32. INSTTTUTO PASTEUR DE SĀO PAULO. Relatório anual de 1904. Sāo Paulo, Augusto Siqueira e Comp., 1905, p. 22. 
jornais de São Paulo, procurava tornar visível, para a sociedade paulistana, o valor científico e assistencial da instituição.

Em maio de 1906, depois de muitas consultas a profissionais estrangeiros, o Instituto conseguiu contratar para dirigir seus trabalhos técnicos o médico Antonio Carini, assistente do Instituto de Bacteriologia Soroterapia e de Moléstias Infecciosas de Berna. No início da sua gestão foram inauguradas novas linhas de pesquisas e a fabricação de novos produtos biológicos. Entre estes constavam a vacina para a tuberculose bovina, os soros anticarbunculoso e antitetânico, a tuberculina, a maleína, a gelatina esterilizada. O Instituto passou a elaborar, também, testes para o diagnóstico da febre tifóide (teste de Widal, ou de aglutinação) e um microrganismo contagioso que servia para o combate biológico aos ratos. Embora aumentasse cada vez mais sua oferta de produtos biológicos, observamos a existência de uma dificuldade crescente na comercialização destes. Os relatórios referem-se com freqüência ao problema, lamentando o fato de que a população, em sua maioria, ainda desconhecia as atividades industriais da instituição.

Nos primeiros anos da administração do Dr. Carini, a Instituição atravessou sua fase de maior prosperidade. No ano de sua chegada, participou da Exposição Zootécnica Estadual, expondo seus produtos de uso veterinário, que lhe valeram uma medalha de ouro. Em 1907, foram reformadas suas instalações e iniciado o curso de bacteriologia e microscopia clínica, sob a direção do próprio Carini. Dividido em um módulo teórico e outro prático, o curso teve uma média de catorze alunos no primeiro ano. Nos anos seguintes, prosseguiu, sempre voltado para a classe média local. Paulatinamente, graças à reputação científica e notoriedade obtidas pelo instituto, muitos médicos e doutorandos se interessaram em desenvolver pesquisas relacionadas à raiva, passando a freqüentá-lo com esse fim.

Ainda em 1907, o Instituto foi equipado com uma seção de Química Analítica e Bromatológica. Para presidi-la foi convidado o químico Francisco Mastrangioli. Sua criação visava aparelhar o Instituto para proceder à análise dos alimentos vendidos no comércio paulista. Já havia sido votada, pelo Legislativo Municipal, uma lei encarregando-o dessa atividade, faltando apenas sua sanção pela prefeitura. As fontes levantadas até agora não nos permitem afirmar se o convênio foi efetivado. A inexistência de qualquer referência a ele nos relatórios posteriores nos leva a crer que não se concretizou, permanecendo esta atividade na órbita do Laboratório de Análises Químicas e Bromatológicas do Serviço Sanitário do Estado. A atividade rotineira da seção de química consistiu então, na produção de 
substâncias químicas de uso terapêutico, ${ }^{33}$ vendidas a indústrias farmacêuticas; na elaboração de análises químicas para algumas indústrias alimentícias e de exames para os médicos da cidade. Entre estes figurava a reação de Wassermann, para o diagnóstico da sífilis, que se tornou uma das principais fontes de rendas do Instituto nos anos posteriores.

Outra atividade que se expandiu na administração de Carini foi o tratamento anti-rábico. Em 1907, a seção dedicada a esta atividade teve suas instalações reformadas e ganhou um novo regulamento mais rigoroso em relaçāo à assepsia. Nos anos seguintes, verificou-se uma epidemia de raiva na capital do estado. O Instituto prontamente aumentou a produção do imunizante e deu início a uma campanha de esclarecimento da população através de panfletos que explicavam a forma de prevenção da doença. Subjugada a epidemia, em 1909, o número de atendimentos voltou a decrescer ${ }^{34}$ Entretanto, a partir de 1912 a quantidade de pessoas à procura de tratamento anti-rábico se elevou tanto que suas instalações passaram a ser insuficientes para os trabalhos de produção e aplicação de vacinas. Nos relatórios do Serviço Anti-rábico, que o Instituto fazia publicar na Revista Médica de São Paulo, seu diretor manifestava constante preocupação com o aumento dos casos de raiva na cidade e com a possível incapacidade do Instituto em atendê-los. "Se continuar no nosso instituto uma tal afluência de doentes tornar-se-á de absoluta necessidade e de toda a urgência providências a fim de obtermos instalações mais amplas." 35

No campo das pesquisas científicas observa-se um aumento substancial no número de trabalhos produzidos no período. Somente no ano de 1907, foram publicadas cerca de 15 comunicaçōes em diversos periódicos e congressos médicos. No ano seguinte esta cifra alcançava 21 trabalhos, continuando a elevar-se nos anos seguintes. As pesquisas eram publicadas principalmente na Revista Médica de São Paulo e na Revista da Sociedade Científica de São Paulo, ou então apresentadas à Sociedade de Medicina e Cirurgia de São Paulo. No plano científico internacional, o Bulletin de la Société de Pathologie Exotique de Paris, os Annales de l'Institut Pasteur

33. Em 1907 a Seção de Química passa a preparar a morfina, cocaína, sparteína, cafeína, óleo canfordo, estricnina, cacodilato de sódio e de ferro, éter sulfúrico. No ano seguinte, a produçāo desta seçāo já atingia 40 preparaçōes.

34. Movimento dos doentes submetidos ao tratamento anti-rábico no Instituto Pasteur de São Paulo.

\begin{tabular}{cccccccccc}
\hline 1904 & 1905 & 1906 & 1907 & 1908 & 1909 & 1910 & 1911 & 1912 & 1913 \\
467 & 453 & 281 & 309 & 616 & 627 & 420 & 583 & 919 & 1060
\end{tabular}

35. Esta declaraçāo do Dr. Carini encontra-se no Relatório do Serviço Anti-rábico do Instituto Pasteur, publicado na Revista Médica de Sâo paulo de maio de 1914. 
e o Centralblatt F. Bakteriologie, Parasitenkunde U. Infektionskrankheiten, de Berlim, eram as publicações a que o Instituto tinha mais acesso.

O número de publicaçōes em periódicos científicos é expressivo e parece indicar que o Instituto havia alcançado reconhecimento junto à comunidade científica do país e do exterior. Indicador igualmente importante de sua vitalidade é a estreita relação de seus trabalhos com os de outras instituições biomédicas voltadas também para investigações na área da saúde pública e da veterinária.

Em 1904, alguns pesquisadores do Instituto se detiveram no estudo da aplicação do soro antiofídico à terapêutica da raiva e da febre amarela. Essa tentativa de cruzamento de soros também era feita por Vital Brasil, no Butantan. Os trabalhos sobre a tinea imbricata, realizados, no mesmo período por Ulysses Paranhos, foram retomados poucos anos depois por Henrique Aragão, no Instituto de Manguinhos. Em 1911, Carini dedicavase ao estudo dos fungos e protozoários, tornando-se um dos pioneiros na descrição do toxoplasma dos pombos e dos cães e na confirmação da existência desse parasita. ${ }^{36}$ Alguns anos depois, seus trabalhos serviram de base a novos estudos, efetuados por pesquisadores do Instituto Oswaldo Cruz que dirigiram suas investigações para a patogenia do parasito. ${ }^{37}$

Em 1910, meses depois de Carlos Chagas haver descoberto a doença que leva o seu nome, Carini voltou-se para o estudo do Trypanosoma Cruzi. Suas pesquisas demonstraram que algumas formas do parasito observadas por Chagas representavam, na verdade, um parasito diferente, não associado à enfermidde. Além disso, seus trabalhos foram importantes por confirmar a existência do mal de Chagas em São Paulo e em Ribeirão Preto, jogando por terra a suposição da raridade e limitada distribuição geográfica desta doença.

Em 1911, o Instituto desenvolveu um importante trabalho em Santa Catarina. O surgimento de uma epizootia desconhecida que atingia o gado da região, trazendo grandes prejuízos aos criadores, era motivo de preocupação no estado. O Dr. Constantino Stroppa, veterinário militar encarregado pelo governo de Santa Catarina de emitir parecer sobre a doença, declarou que se tratava de peste bovina. Tal diagnóstico deixou em polvorosa os pecuaristas das regiōes vizinhas devido à gravidade e facilidade

36. Cf. REIS, op. cit., p. 6.

37. A importância dos trabalhos no Instituto Pasteur no desenvolvimento de pesquisas posteriores em outras instituiçōes foi observado através da leitura da obra de FONSECA FILHO, Olympio da "A Escola de Manguinhos: contribuiçāo para o estudo do desenvolvimento da medicina experimental no Brasil", separata do tomo II de Oswaldo Cruz -Monumenta Histórica. Sāo Paulo, 1974. [FONSECA Filho, 1974:70] 
de propagação desta zoonose. Outro bacteriologista chamado a estudar o problema foi Parreiras Horta, do Instituto Oswaldo Cruz, que diagnosticou a existência de uma nova entidade mórbida dos animais de raça bovina e cavalar.

Temendo que a epizootia invadisse São Paulo, o secretário de Agricultura do estado, enviou Carini à Santa Catarina para estudar o problema. Nas localidades atingidas, Carini recolheu grande quantidade de material para ser analisado no Instituto. Em menos de um mês, apresentou um relatório constatando que a zoonose era hidrofobia. O diagnóstico tranqüilizou os criadores da região fronteiriças, dada a possibilidade de controle da moléstia. Posteriormente, suas conclusões foram admitidas por Parreiras Horta e confirmadas pelos técnicos argentinos e uruguaios que estiveram na região para estudar a doença.

As observaçōes feitas por Carini em Santa Catarina, o levaram à conclusão pioneira de que os morcegos eram possíveis transmissores da raiva aos bovinos. "Carini observou que uma epizootia de tão grandes proporções não poderia ter sido desencadeada pela mordedura de cães. Relatos de habitantes locais incriminavam os morcegos, e Carini apontouos como os prováveis transmissores. Esta hipótese foi definitivamente comprovada somente vinte anos depois, com o isolamento do vírus rábico nesta espécie." ${ }^{38}$

O trabalho de Carini teve grande ressonância na opinião pública. Quando regressou a São Paulo, os jornais da capitaI estamparam diversas notícias sobre a descoberta, ressaltando a veracidade de suas conclusões, face às opiniōes equivocadas dos outros médicos que haviam estudado a moléstia.

Embora o Instituto Pasteur de São Paulo tenha sido a primeira instituição a afirmar a existência da raiva em Santa Catarina, contradizendo as opiniões dos médicos do Instituto Oswaldo Cruz, suas atividades se encerraram com o diagnóstico da zoonose. O governo federal, interessado em debelar um problema que poderia se alastrar pelas zonas pastoris mais importantes do país, encarregou o Instituto Oswaldo Cruz de prestar assessoria ao governo de Santa Catarina no enfrentamento à epizootia. Lutando contra a resistência de grande parte da população e dos criadores, que não admitiam que seu gado fosse abatido para o controle da epizootia, os cientistas do IOC colocaram em prática um programa anti-rábico que

38. GAMBETTA, Wilson Roberto; CAMELET, Esther Luiza Bocato; SOUZA, Luiza T. Nadia; AZEVEDO, Murilo Pacca. Instituto Pasteur de São Paulo, 75 anos de atividade: 1903-1978. São Paulo, Imprensa Oficial do Estado, 1979. 
consistia na eliminação dos animais suspeitos de hidrofobia e na vacinação das pessoas atingidas. Para dar cabo desse programa foi montado um Instituto Pasteur na localidade, que ficou incumbido da preparação da vacina anti-rábica.

\section{O ocaso do Instituto Pasteur de São Paulo}

Em 1912, a morte de Inácio Cochrane provocou uma desorganização da administração do Instituto. Os relatórios de atividades por ele confeccionados anualmente deixaram de existir. As atas de registro de doações e subvenções também se extinguiram, e as reuniōes da Comissão Permanente tornaram-se cada vez mais esporádicas. A dificuldade de obter fontes que se refiram às atividades do Instituto nos anos seguintes nos impede de elaborar uma análise mais detalhada sobre o período. Entretanto, o estudo de fontes externas ao Instituto nos permite afirmar que, entre 1912 e 1914, os trabalhos de pesquisa, tratamento anti-rábico e produção de imunizantes continuaram em níveis próximos aos observados para os anos anteriores.

O ano de 1915 marca o início da crise que, rapidamente, culminaria com a desagregação do Instituto. No seu cerne encontra-se a interrupção das subvenções efetuadas pelo estado. Entretanto, outras questōes se interrelacionam para provocá-la.

Uma delas é a mudança de atitude da opinião pública frente ao Dr. Carini e ao Instituto. O exame do material jornalístico mostra que, depois de assumir a direção do Instituto, Carini transformou-se rapidamente numa figura conhecida entre os médicos da capital. De início, o reconhecimento de suas atividades profissionais restringia-se à colônia italiana, com a qual manteve boas relações, tornando-se inclusive, diretor da Sociedade Dante Alighiere para a Difusão da Língua e da Cultura Italiana. Com o passar dos anos, seus trabalhos no Instituto e a Sociedade de Medicina e Cirurgia de São Paulo fizeram com que seu prestígio ultrapassasse as fronteiras herdadas pela nacionalidade. A partir do episódio da raiva em Santa Catarina, Carini começou a atrair, cada vez mais, a atenção da imprensa; suas opiniões sobre questões médicas e veterinárias passaram a ser veiculadas com grande destaque pelos jornais paulistas.

Em 1911, foi fundado o Instituto Universitário de São Paulo - instituição particular de ensino superior, amparada pela lei que garantia o ensino livre. No ano seguinte, o estado inaugurou a Faculdade de Medicina e Cirurgia de São Paulo. Em 1914, Carini foi nomeado diretor da Escola de Medicina do Instituto Universitário. Um ano depois, abandonou esta instituição para assumir o cargo de lente de bacteriologia na Faculdade de 
Medicina. No mesmo ano, o Conselho Superior de Ensino revogou a lei que autorizava o funcionamento do Instituto Universitário, fazendo com que este deixasse de existir em 1917. A cassação deste estabelecimento criou grande animosidade entre os partidários do ensino livre e do ensino oficial em São Paulo. Por sua transferência para a Faculdade do governo, Carini se tornou alvo constante dos defensores da liberdade de ensino principalmente dos alunos do Instituto Universitário - que, através do jornal $O$ Combate, dirigiam-lhe violentas críticas.

O turbilhão que envolveu Carini enredou, também, o Instituto Pasteur. Seus detratores passaram a acusar o Instituto de diversas irregularidades, que iam da elaboração imperfeita de exames bacteriológicos à compra de soros em estabelecimentos farmacêuticos, cujos rótulos seriam adulterados para que fossem revendidos como produtos de sua fabricação.

No momento em que os ânimos se exaltavam contra o Instituto e seu diretor, desenrolava-se a crise financeira que culminaria com a integração do Instituto Pasteur ao Serviço Sanitário. Em 1915, as subvenções do estado foram interrompidas, dificultando a manutenção das atividades da instituição. $\mathrm{O}$ estancamento de sua principal fonte de rendas ocorreu num momento que, em virtude da elevação dos índices da hidrofobia no Estado, o Instituto apresentava dificuldades em dar conta do afluxo de pessoas que batiam à sua porta em busca de tratamento. Dificuldade esta, que se mostrou ainda mais grave porque a Santa Casa passou a se recusar, a partir de então, a abrigar os pacientes vindos do interior, alegando falta de espaço. A crise levou o Serviço Sanitário a iniciar, naquele ano, estudos contemplando a instalação de um serviço anti-rábico oficial no Instituto Bacteriológico, decisão que coincidiu com a interrupção das subvenções oficiais ao Instituto Pasteur de São Paulo.

Num esforço para reduzir o estrangulamento criado com o fim destas subvenções, o presidente de seu conselho diretor, J. J. Nova, promoveu uma série de reformas na instituição. A seção administrativa teve seu pessoal diminuído; o tesoureiro foi instruído a aplicar as sobras de rendas do Instituto; a seção de biologia foi estimulada a aumentar sua produçāo de terapêuticos e imunizantes com a finalidade de intensificar a comercialização, e seu diretor técnico teve seu salário reduzido.

Contudo, as mudanças não possibilitaram a recuperação do Instituto. A gravidade dos problemas financeiros fez com que seu Conselho Diretor decidisse, após muitas controvérsias, doá-lo ao Serviço Sanitário. Segundo a maioria de seus integrantes, a doação não implicaria a descaracterização da instituição, que continuaria a prestar os mesmos serviços à sociedade. Manifestaram-se contra esta posição os Drs. Carini e Ulysses Paranhos, que 
ainda apostavam na continuidade da administraçāo fora do Estado. Na tentativa de preservar as bases originais do Instituto, os dois pesquisadores tentaram embargar a doação na justiça. Entretanto, sua iniciativa não surtiu efeito e, mesmo antes da transferência, foram demitidos. Em agosto de 1916, concretizou-se a incorporaçāo do Instituto ao Serviço Sanitário do Estado. Nesse momento, seu pessoal técnico foi drasticamente reduzido e seus trabalhos de pesquisa abandonados por longo período. ${ }^{39}$

Meses antes da incorporação, Ulysses Paranhos fundou o Laboratório Paulista de Biologia. Com a desagregação do Instituto, seu diretor e vários outros técnicos se incorporaram ao laboratório. Aproveitando a experiência adquirida no Instituto, esses médicos logo passaram a oferecer produtos e serviços muito semelhantes aos do Instituto Pasteur. Para assegurar a procura, iniciaram a publicação de uma revista dirigida aos médicos paulistas. Ela não se destinava a veiculação dos trabalhos do laboratório, e sim de outras instituições e de clínicos paulistas, entremeando anúncios de seus produtos entre os artigos publicados. Com um caráter puramente empresarial, o Laboratório Paulista de Medicina daria continuidade às atividades do Instituto Pasteur que se integravam, agora definitivamente, ao mercado.

\section{O estrangulamento financeiro do Instituto}

Até aqui nos detivemos na trajetória do Instituto. Passaremos agora a analisar sua forma de financiamento, e como esta esteve intimamente relacionada à sua decadência.

Como observamos anteriormente, o Instituto tinha como fonte de rendas as doações de particulares, as subvenções oficiais e a venda de seus produtos e serviços. A primeira forma de dotação se mostrou bastante instável. Os donativos que concorreram para a sua fundação e manutenção, no primeiro ano de sua história, foram bastante vultosos, ascendendo ao patamar de $63 \%$ da receita total. Tal valor era, neste momento, duas vezes superiores à soma das subvençōes das agências governamentais. Nos anos seguintes, esta dotação foi gradativamente se reduzindo, deixando de ser uma fonte de recursos expressiva (ver tabela). Em 1911, momento em que estas quantias deixam de ser registradas no livro caixa da instituição, as

39. Pelo decreto-lei 1525 , de 13 de agosto de 1916 o Instituto Pasteur passa a fazer parte do organograma do Serviço Sanitário do Estado de Sảo Paulo. "As finalidades deste novo órgảo fixadas pela lei eram: a) 'Tratamento preventivo das pessoas mordidas por animais raivosos ou suspeitos'; b) 'Conselhos que deverá dar o Instituto às autoridades e aos particulares sobre as medidas preventivas aplicáveis à raiva'; c) 'Fixaçāo de diagnósticos de animais vivos ou mortos suspeitos de raiva e enviados ao Instituto para esse fim'." (MASCARENHAS, op. cit., p. 68) 
doações auferidas pelo Instituto não chegam a totalizar $2 \%$ de sua receita. Vale notar a inconstância das doações recebidas pelo instituto, que variavam de acordo com a boa vontade da filantropia paulista. Em 1908, por exemplo, o Instituto recebeu um donativo de 20 contos de réis do Sr. Inácio Penteado, saldando com esta quantia grande parte da dívida feita com a compra do prédio de sua sede. No ano seguinte, a soma de todos os donativos auferidos não chegou a um décimo desse montante.

As subvençōes oficiais dividiam-se em três rubricas diferentes: do governo federal, do governo do estado de São Paulo e das Câmaras Municipais de cidades paulistas. Nos anos de 1904, 1906 e 1908 o Instituto contou com uma fonte de renda extra, advinda dos socorros públicos do Estado. ${ }^{40}$

A subvenção do Governo Federal se iniciou em 1907, com a quantia de 10 contos de réis. Em 1909 esta dotação foi interrompida, voltando a ser efetuada em 1910, 1911 e 1912, com o valor absoluto duplicado. As observações do presidente do Instituto, contidas nos relatórios de atividades anuais, nos possibilitam inferir que essa fonte de recursos era instável e, normalmente, não se esperava a sua continuidade. ${ }^{41}$

As subvençōes das Câmaras Municipais não sofreram grandes variações até o ano de 1911, momento em que começaram a diminuir sensivelmente. Embora não saibamos com exatidão o montante correspondente às subvenções ef etuadas pelas Câmaras a partir de 1912, as atas das reuniões da Comissão Permanente informam que estas foram diminuindo progressivamente, até serem extintas, em 1915. Acreditamos que esta redução se relacionou a uma reforma dos serviços sanitários, havida em 1911. Nesse momento, os serviços de saúde do estado tiveram o raio de ação da maioria de suas atividades reduzido ao âmbito da capital. As municipalidades passaram a se responsabilizar pela organização de seus serviços sanitários.

40. Os socorros públicos eram verbas previstas no orçamento do estado de Sấo Paulo para a utilizaçāo em casos de epidemia. Entretanto seu uso se relacionou muito mais a interesses políticos que sociais. "Cada deputado tinha uma certa proporção dessa verba a ser distribuída pelos hospitais de sua zona eleitoral, sem controle algum por parte das autoridades sanitárias. (...) Em vésperas de eleiçōes, essas verbas eram muito aumentadas, quer diretamente, quer indiretamente, através de suplementaçóes, o que mostra o cunho político das mesmas."(MASCARENHAS, op. cit., p. 18).

41. Ao explicar a situaçāo financeira do Instituto, em 1909, seu presidente observava: "A diminuiçāo da receita se explica, primeiramente, pelo fato de figurarem no ano anterior o valioso e excepcional donativo do sócio Benemérito e Benfeitor Sr. Inácio Penteado e a subvençāo do Governo Federal (...)”. (RELATÓRIO DO INSTTTUTO PASTEUR DE SĀO PAULO, 1910:18). No ano seguinte, ao se referir à melhoria da situaçảo financeira da instituiçāo, afirma: "Para a consecução de tāo lisongeiros resultados, muito contribuíram avultados donativos de alguns de seus sócios beneméritos, bem como o fato de terem sido recebidas no ano passado as subvençōes do Governo Federal; circunstâncias estas que, excepcionalmente, se podem repetir." (idem, 1912:4). 
Esta nova orientação, ao ampliar a competência dos municípios frente aos problemas locais de saúde, contribuiu para o desinteresse na manutenção do Instituto, pois a vacinaçāo contra doenças transmissíveis era uma das atividades que ainda estava sob a responsabilidade do estado.

Outro dois aspectos se relacionam ao decréscimo da subvenção advinda das Câmaras Municipais: em primeiro lugar, a restrição das verbas foi uma conseqüência das dificuldades do Instituto em fazer com que seu conjunto de atividades fossem reconhecidas nas regiões interioranas. Embora oferecesse tratamento a um grande número de pessoas vindas dessas regiōes, as atividades de pesquisa científica não geram resultados prontamente aplicáveis. Por outro lado, o desenvolvimento dos institutos de pesquisa e produção de imunizantes vinculados ao estado fazia com que fosse diminuído o interesse dos poderes públicos municipais por uma instituição particular, dependente de subvenções externas.

As dotações do Governo de São Paulo se iniciaram com a fundação do Instituto e permaneceram com valores absolutos crescentes até a sua extinção em 1915. O estancamento da subvenção do Estado ligou-se, também, ao desenvolvimento de outras instituições, oficiais, que passaram a efetuar algumas atividades, anteriormente exercidas somente pelo Instituto. Em 1912, foi fundada a Faculdade de Medicina do Estado de São Paulo. Esta viria a cumprir uma das funções do Instituto Pasteur, a especialização médica. Dois anos depois, o Instituto Butantan passou por uma reforma em suas instalaçōes e iniciou um período de intenso desenvolvimento, passando inclusive a fabricar produtos biológicos, antes elaborados somente no Instituto Pasteur. Em 1915, o Serviço Sanitário elaborou um projeto para criar um serviço anti-rábico no Instituto Bacteriológico e interrompeu as subvenções para o Instituto Pasteur. Em abril de 1916, meses antes da incorporaçāo do instituto ao Serviço Sanitário, foi instalada uma seção para a produção do imunizante anti-rábico no Instituto Bacteriológico.

A venda de produtos biológicos e a elaboraçāo de exames e análises representaram uma fonte de renda fundamental para a manutenção do Instituto. Em 1911, data da publicação do seu último relatório, esta já perfazia 55\% de sua receita. Entretanto, em 1915, quando foram interrompidas as dotações do estado, esta fonte de renda não se mostrava suficiente para a manutenção do instituto, o que fez seu diretor incentivar a comercialização dos produtos biológicos para garantir o prosseguimento de suas atividades. No nosso entender, embora essa fonte de renda se mantivesse ascendente, ela era cada vez mais limitada pela expansão dos institutos 
oficiais e privados que realizavam exames laboratoriais e produziam imunobiológicos e outros terapêuticos.

Os laboratórios oficiais muitas vezes distribuíam seus produtos gratuitamente - em casos de epidemias, por exemplo - ou a preços subsidiados. Instituições como o Instituto Oswaldo Cruz e o Butantan, aproveitando sua infra-estrutura, concentraram esforços na produção de imunizantes - principalmente os de uso veterinário - e posteriormente de quimioterápicos para a comercialização no mercado nacional.

Tomemos como exemplo dessa concorrência a comercializaçào da vacina contra o carbúnculo sintomático — zoonose bovina também conhecida como peste da manqueira. A partir de 1905, o Instituto Pasteur passou a produzir este imunizante. No entanto, são comuns, em seus relatórios, afirmações relativas às dificuldades de comercialização do produto, em virtude do pouco interesse dos criadores. Somente a partir de 1908, devido a uma epizootia havida no interior de São Paulo, o Instituto conseguiu elevar, temporariamente, a sua venda.

Em 1907, Alcides Godoy desenvolveu, no Instituto Oswaldo Cruz, uma nova técnica para a elaboração dessa vacina. O IOC patenteou a técnica $\mathrm{e}$ passou a comercializar o produto. Em poucos anos foi montado um grande esquema de produção e comercialização que contava até com um propagandista itinerante que visitava as regiões interioranas, com a finalidade de convencer os criadores da eficácia da vacina. Já em 1911, a renda auferida pelo IOC, somente com a venda dessa vacina, atingia a cifra de 112 contos de réis. ${ }^{42}$ Neste mesmo ano, a soma de toda a renda advinda da venda de produtos e serviços do Instituto Pasteur era de aproximadamente 76 contos de réis.

Além dos laboratórios oficiais, o Instituto enfrentava a concorrência dos laboratórios privados que iam se multiplicando pela cidade. Estes, não mantendo atividades assistenciais, restringindo a pesquisa somente às que pudessem gerar novas drogas e investindo na propaganda de seus produtos, tinham como efetuar exames laboratoriais e colocar sua produção de imunizantes e terapêuticos no mercado a preços menores e de forma mais eficiente.

\section{Conclusão}

No capítulo em que tratamos da criação e do desenvolvimento do Instituto Pasteur de São Paulo, observamos sua clara inspiração em seu homônimo

42. BENCHIMOL J., op. cit., p. 274.

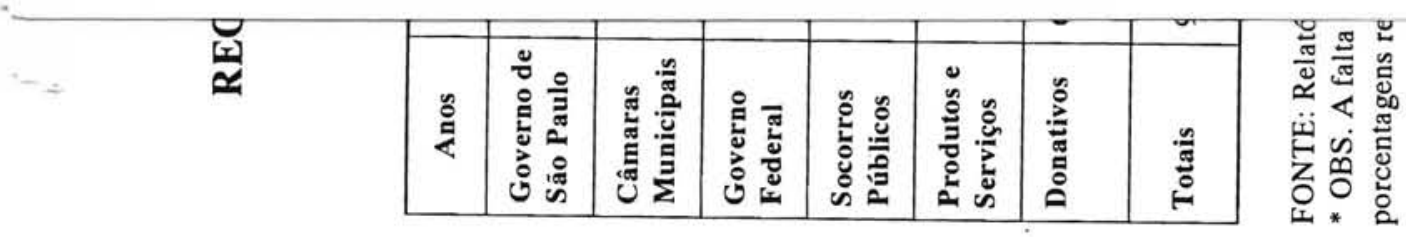


francês. Vejamos, agora, alguns aspectos da decadência do Instituto paulista, em contraponto com o seu congênere da França.

O Instituto parisiense teve sua criação determinada pelo grande sucesso conseguido por Pasteur com seus trabalhos sobre imunização. Quando foi inaugurado, Pasteur já era considerado um herói nacional, o que garantiu um grande afluxo de recursos públicos e privados para a sua instituição. Além disso, seus trabalhos se mostravam, para a sociedade francesa, como uma nova esperança frente as epidemias que, a despeito da atuação higienista, avançavam pari passu à expansão industrial e urbana.

Nos anos subseqüentes à criação do Instituto francês, a difusão da ciência bacteriológica serviria, ainda, como ponto de apoio ao desenvolvimento imperialista, revelando-se de grande importância para a manutenção dos interesses coloniais da França na África e no Extremo Oriente. A partir de 1889 foram fundados diversos institutos filiais em suas novas colônias e possessões, permitindo em muitos casos o controle de doenças tropicais que dificultavam as atividades dos colonizadores nestas regiōes.

Este contexto possibilitou a existência de uma demanda sempre crescente para os produtos e serviços do Instituto. Esta se conjugou a um esforço de propagar o novo campo das ciências e ratificá-lo frente à comunidade científica. Com esse intuito, antes mesmo da inauguração oficial do Instituto, foram criados os seus anais, que rapidamente se transformaram em referência para diversas áreas ligadas às ciências biomédicas. Os cursos de técnicas bacteriológicas, oferecidos pelo Instituto a partir de 1894, também contribuiriam nesse sentido, formando novos pesquisadores capazes de desenvolver ainda mais esse novo campo científico.

A inauguração do Instituto Pasteur de São Paulo ocorreu num contexto diferenciado. Mesmo sem ter à frente uma personalidade mitificada pela sociedade, e não contando com um interesse pelo desenvolvimento científico nos níveis do observado pelo instituto parisiense, seus fundadores conseguiram articular diversos setores da sociedade em favor de uma instituição filantrópica que, tendo como atividade mais visível a cura da raiva, procurava desenvolver pesquisas nas áreas relativas às doenças tropicais. Entretanto, o Instituto logo sentiria os efeitos de estar imerso numa realidade diferente.

Ao comparar o contexto de criação do Instituto Oswaldo Cruz com o do Instituto Pasteur de Paris, Nancy Stepan observa que a criação de institutos científicos no âmbito do Estado se deveu à inexistência de patrocínio privado à ciência nacional. "Nenhuma tradição de patrocínio particular da ciência existia no Brasil, e o valor atribuído à ciência era 
pequeno demais para tornar tal patrocínio um método exequiível de encorajar o seu desenvolvimento. Nāo existia nenhum Carnegie ou Rockefeller, cujas fortunas adquiridas na indústria pudessem ser postas agora a serviço da pesquisa científica". ${ }^{43}$

A observação da história do Instituto Pasteur de São Paulo nos impede de ser tão categóricos em relação à inexistência de patrocínio privado à ciência. Entretanto, temos que admitir que a instabilidade desses recursos e mesmo sua ordem de grandeza não eram suficientes para assegurar o sucesso do projeto pensado para o Instituto. Como vimos, as doações que contribuíram para sua instalaçāo e expansão inicial logo se mostraram residuais. Em nosso entender, mesmo se estas se mantivessem nos níveis observados nos primeiros anos não seriam suficientes para a manutenção de uma atividade científica que, ao se especializar, se tornava cada vez mais dependente de equipamentos caros. observação da história do Instituto Pasteur de São Paulo nos impede de ser tão categóricos em relação à inexistência de patrocínio privado à ciência. Entretanto, temos que admitir que a instabilidade desses recursos e mesmo sua ordem de grandeza não eram suficientes para assegurar o sucesso do projeto pensado para o Instituto. Como vimos, as doações que contribuíram para sua instalação e expansão inicial logo se mostraram residuais. Em nosso entender, mesmo se estas se mantivessem nos níveis observados nos primeiros anos não seriam suficientes para a manutenção de uma atividade científica que, ao se especializar, se tornava cada vez mais dependente de equipamentos caros.

Quando da inauguração do Instituto Pasteur de São Paulo, poucas instituições paulistas se dedicavam às atividades por ele desempenhadas. O Instituto Bacteriológico e o Butantan já desenvolviam pesquisas biomédicas, mas estas se restringiam às doenças humanas. A produção de imunizantes era feita somente nos Institutos Butantan e Vacinogênico. O primeiro dedicava-se prioritariamente à fabricação do soro e vacina antipestosos e dos soros antiofídicos, o segundo elaborava a vacina antivariólica. Na área do ensino da bacteriologia, São Paulo ainda se ressentia da inexistência de uma faculdade de medicina. Nesse contexto, o Instituto Pasteur de São Paulo, tal como o parisiense, teve pela frente um grande campo de atuação que lhe permitiu um rápido desenvolvimento. Mas suas iniciativas de prover o Estado de São Paulo de serviços e produtos advindos da pesquisa microbiológica acabaram frustradas pelo desenvolvimento da rede institucional diretamente ligada ao Estado. Suas pesquisas e

43. STEPAN N., op. cit., p. 79. 
preparaçōes biológicas se aproximavam das que aos poucos começaram a se desenvolver nos institutos oficiais; o ensino da bacteriologia passou a ser função das escolas médicas criadas a partir de 1911. O desenvolvimento dessas instituições fez com que aos poucos fosse enfraquecendo a demanda pelos seus produtos e, talvez, o interesse em suas pesquisas.

No nosso entender, o espaço de ação do instituto paulista estava definido pelo raio de atividades das instituiçōes oficiais. Acreditamos que a competição com estes institutos pelos escassos recursos governamentais e a concorrência - das instituições públicas e privadas - na comercialização dos produtos biológicos foram os fatores decisivos na sua decadência.

\section{RESUMO}

\section{O Instituto Pasteur de São Paulo: uma contribuição a história das instituições biomédicas no Brasil}

O texto procura analisar a trajetória do Instituto Pasteur de São Paulo, instituição científica filantrópica, criada em 1903 por médicos paulistas, nos moldes do Instituto Pasteur de Paris. A história científica e administrativa dessa instituição é abordada no contexto do desenvolviento dos institutos bacteriológicos oficiais fundados na capital paulista a partir da última década do século passado. Devido à semelhança entre o instituto paulista e o instituto Pasteur de Paris, procuramos fazer um contraponto entre o modelo organizacional dessas duas instituições, tentando depreender daí as possibilidades e as limitações advindas da tentativa de recriação de um modelo institucional numa formação social diferenciada da que o originou.

\section{ABSTRACT \\ São Paulo's Pasteur Institute: a contribution for the hystory of Brazilian biomedical institutions}

The text tries to analyse São Paulo's Pasteur Institute: a philanthropic scientific institution, founded in 1903 by psysicians from São Paulo, following the patterns of Paris' Pasteur Institute. The institution's scientific and administrative hystory is focused within the context of the 


\section{RECURSOS OBTIDOS PELO INSTITUTO PASTEUR DE SÃO PAULO 1904-1912}

(montante de renda em contos de réis e porcentagem da receita total)

\begin{tabular}{|c|c|c|c|c|c|c|c|c|c|}
\hline Anos & 1904 & 1905 & 1906 & 1907 & 1908 & 1909 & 1910 & 1911 & 1912 \\
\hline $\begin{array}{l}\text { Governo de } \\
\text { São Paulo }\end{array}$ & $\begin{array}{c}8: 000 \$ 000 \\
8,3 \%\end{array}$ & $\begin{array}{c}12: 000 \$ 000 \\
29,2 \%\end{array}$ & $\begin{array}{c}15: 000 \$ 000 \\
34,8 \%\end{array}$ & $\begin{array}{c}25: 000 \$ 000 \\
32,4 \%\end{array}$ & $\begin{array}{c}18: 7505000 \\
18,1 \%\end{array}$ & $\begin{array}{c}29: 166 \$ 620 \\
40,7 \%\end{array}$ & $\begin{array}{c}25: 0005000 \\
23,7 \%\end{array}$ & $\begin{array}{c}25: 000 \$ 000 \\
18 \%\end{array}$ & $25: 000 \$ 000$ \\
\hline $\begin{array}{l}\text { Câmaras } \\
\text { Municipais }\end{array}$ & $\begin{array}{c}23: 945 \$ 000 \\
24,7 \%\end{array}$ & $\begin{array}{c}19: 1705000 \\
46,6 \%\end{array}$ & $\begin{array}{c}19: 365 \$ 000 \\
44,9 \%\end{array}$ & $\begin{array}{c}19: 250 \$ 000 \\
24,9 \%\end{array}$ & $\begin{array}{c}21: 2005000 \\
20,5 \%\end{array}$ & $\begin{array}{c}18: 050 \$ 000 \\
25,2 \%\end{array}$ & $\begin{array}{c}23: 419 \$ 993 \\
22,2 \%\end{array}$ & $\begin{array}{c}14: 940 \$ 000 \\
10,7 \%\end{array}$ & $12: 000 \$ 000$ \\
\hline $\begin{array}{l}\text { Governo } \\
\text { Federal }\end{array}$ & & & & $\begin{array}{c}10: 000 \$ 000 \\
13 \%\end{array}$ & $\begin{array}{c}10: 000 \$ 000 \\
9,7 \%\end{array}$ & & $\begin{array}{c}20: 0005000 \\
18.9 \%\end{array}$ & $\begin{array}{c}20: 0005000 \\
14,4 \%\end{array}$ & $20: 000 \$ 000$ \\
\hline $\begin{array}{l}\text { Socorros } \\
\text { Públicos }\end{array}$ & $\begin{array}{c}3: 000 \$ 000 \\
3,1 \%\end{array}$ & & $\begin{array}{c}4: 000 \$ 000 \\
9,3 \%\end{array}$ & & $\begin{array}{c}4: 000 \$ 000 \\
3,9 \%\end{array}$ & & & & \\
\hline $\begin{array}{l}\text { Produtos e } \\
\text { Serviços }\end{array}$ & $\begin{array}{c}760 \$ 000 \\
0,8 \%\end{array}$ & $\begin{array}{c}2: 819 \$ 000 \\
6,8 \%\end{array}$ & $\begin{array}{c}3: 670 \$ 650 \\
8,5 \%\end{array}$ & $\begin{array}{c}13: 147 \$ 760 \\
17 \%\end{array}$ & $\begin{array}{c}23: 326 \$ 350 \\
22,5 \%\end{array}$ & $\begin{array}{c}22: 667 \$ 550 \\
31,6 \%\end{array}$ & $\begin{array}{c}36: 085 \$ 050 \\
34,2 \%\end{array}$ & $\begin{array}{c}76: 793 \$ 400 \\
55,2 \%\end{array}$ & \\
\hline Donativos & $\begin{array}{c}61: 104 \$ 150 \\
63,1 \%\end{array}$ & $\begin{array}{c}7: 144 \$ 000 \\
17,4 \%\end{array}$ & $\begin{array}{c}1: 087 \$ 300 \\
2,5 \%\end{array}$ & $\begin{array}{c}9: 799 \$ 000 \\
12,7 \%\end{array}$ & $\begin{array}{c}26: 200 \$ 000 \\
25,3 \%\end{array}$ & $\begin{array}{c}1: 760 \$ 000 \\
2,5 \%\end{array}$ & $\begin{array}{c}1: 050 \$ 000 \\
1 \%\end{array}$ & $\begin{array}{c}2: 414 \$ 997 \\
1,7 \%\end{array}$ & \\
\hline Totais & $96: 809 \$ 150$ & $41: 133 \$ 000$ & $43: 122 \$ 950$ & $77: 196 \$ 760$ & $103: 476 \$ 350$ & $71: 644 \$ 170$ & $105: 555 \$ 043$ & $139: 148 \$ 397$ & \\
\hline
\end{tabular}

FONTE: Relatórios do Instituto Pasteur de São Paulo e Anuário Estatístico do Estado de Sāo Paulo (1912).

* OBS. A falta dos valores relativos aos produtos e serviços e aos donativos nos impede de apresentar as

porcentagens referentes ao ano de 1912 . 
development of official bacteriological institutes founded in São Paulo's capital since the last decade of the $19^{\text {th }}$ century. Because of the similarity between São Paulo's and Paris' institutes, we tried to make a counterpoint between the organizational models of both institutions, trying to infer from it what are the possibilities and limitations arising from the attempt to recreate an institutional pattern, within a social formation which is different from the one that originated it.

\title{
RESUME
}

\section{L'Institut Pasteur à São Paulo: une contribuition à l'histoire des instituitions biomédicales du Brésil}

Ce texte a comme but analyser l'histoire de l'Institut Pasteur à São Paulo. Cette instituition scientifique et philanthropique a étè crée en 1903 par des médicins locales selon le modèle de l'Institut Pasteur à Paris. Son histoire scientifique et administrative a étè analysé comparativement face au modèle parisien original avec le propos de vérifier les limites et les possibilités posés par le processus de création d'un nouveau modèle d'organisation pour l'institution brésilienne.

\author{
IMPRESSÃO:

